IZA DP No. 8728

Sex Ratios, Polygyny, and the Value of Women in Marriage: A Beckerian Approach

Shoshana Grossbard

December 2014 


\title{
Sex Ratios, Polygyny, and the Value of Women in Marriage: A Beckerian Approach
}

\author{
Shoshana Grossbard \\ San Diego State University \\ and IZA
}

Discussion Paper No. 8728

December 2014

\author{
IZA \\ P.O. Box 7240 \\ 53072 Bonn \\ Germany \\ Phone: +49-228-3894-0 \\ Fax: +49-228-3894-180 \\ E-mail: iza@iza.org
}

\begin{abstract}
Any opinions expressed here are those of the author(s) and not those of IZA. Research published in this series may include views on policy, but the institute itself takes no institutional policy positions. The IZA research network is committed to the IZA Guiding Principles of Research Integrity.

The Institute for the Study of Labor (IZA) in Bonn is a local and virtual international research center and a place of communication between science, politics and business. IZA is an independent nonprofit organization supported by Deutsche Post Foundation. The center is associated with the University of Bonn and offers a stimulating research environment through its international network, workshops and conferences, data service, project support, research visits and doctoral program. IZA engages in (i) original and internationally competitive research in all fields of labor economics, (ii) development of policy concepts, and (iii) dissemination of research results and concepts to the interested public.
\end{abstract}

IZA Discussion Papers often represent preliminary work and are circulated to encourage discussion. Citation of such a paper should account for its provisional character. A revised version may be available directly from the author. 
IZA Discussion Paper No. 8728

December 2014

\title{
ABSTRACT
}

\section{Sex Ratios, Polygyny, and the Value of Women in Marriage: A Beckerian Approach}

\begin{abstract}
A central component of his theory of marriage Becker's Demand and Supply (D\&S) models of marriage are also among the most unique models he pioneered. Here I provide an overview of Becker's analysis of the effects of sex ratios - the ratio of men to women in marriage markets - on individual consumption of married men and women, and indicate some of the ways that this analysis has been expanded and tested. Becker also used D\&S analysis to develop his argument that polygyny benefits women and used the positive association between brideprice and polygyny as evidence. Relying on D\&S models of marriage and based on the section of Becker's Treatise on the Family dealing with "price" rigidities in marriage it is shown that polygyny may be harmful to women. Furthermore, the positive association between brideprice and polygyny does not necessarily prove that women are better off under polygyny than under monogamy.
\end{abstract}

JEL Classification: J12, J16

Keywords: economics of marriage, Gary Becker, sex ratios, bride price, polygyny

Corresponding author:

Shoshana Grossbard

Department of Economics

San Diego State University

San Diego, CA 92182-4485

USA

E-mail: sgrossba@mail.sdsu.edu 


\section{Introduction}

Gary Becker's theories of marriage were mentioned as one of the reasons why he was awarded the Nobel prize in economics in 1992 and were emphasized by Becker: his first article on the family published in a major journal (Becker 1973) is a theory of marriage ${ }^{1}$ and the chapters on marriage in his influential Treatise on the Family (Becker 1981, 1991) come first. ${ }^{2}$ Becker's theoretical models of marriage all view marriages as small non-profit firms engaged in household production, thereby featuring one of the basic tenets of the New Home Economics that Becker pioneered with Jacob Mincer while both were at Columbia University in the 1960s (see Becker 1960, 1965; Mincer 1962, 1963).

This article focuses on a few applications of Becker's theory of marriage that he analyzed using demand and supply (D\&S) graphs. ${ }^{3}$ All D\&S models of marriage are Transferable Utility (TU) models, utility or the means to obtain utility being transferred between men and women in the case of heterosexual marriages. Advantages of D\&S analyses of marriage include simplicity and compatibility with well-known price-theoretical models of markets for goods and resources. Consequently, relative to other models of marriage such as some of those discussed in Chiappori (2015) price-theoretical D\&S models of marriage can more easily be integrated into general equilibrium that simultaneously consider marriage markets and markets of more interest to traditional economists, such as labor markets and markets for goods.

In a section on the distribution of marital output Becker (1973) first introduces D\&S graphs in order to show how sex ratios (the relative numbers of men and women in marriage markets) affect the implicit prices of men and women in marriage, defined as shares of marital income. In the Treatise Becker (1981) also uses D\&S models of marriage to analyze sex ratio effects on price (and individual wellbeing) in marriage. Section 2 of this article reviews Becker's models on sex ratio effects, reports some recent evidence supporting Becker's main prediction and discusses some expansions of Beckerian D\&S models of sex ratio effects with implications for labor supply and savings.

Another major application of D\&S models in Becker's economics of marriage is to the study of polygyny, the subject of Section 3. Its focus is on a question that Becker addressed: is polygyny good for women? Becker's answer was positive. My answer, based on another application of D\&S analysis found in Becker's theory of marriage, namely that of price ceilings in marriage markets is more ambiguous. Men may simultaneously impose polygyny and prevent women from capturing their share of marital output established at the market equilibrium. This section also examines the connection between polygyny and bride price.

\section{Sex ratios Effects}

2.1 Becker on sex ratio effects. Becker focused on sex ratio effects for outcomes directly related to marriage markets, examining both the quantity dimension (how many marry; do they marry monogamously or not) and the price dimension. My focus here is on that price dimension. Becker defined a person's implicit price in marriage in terms of his or her share of marital income, which directly impacts personal consumption. That sex ratios are expected to influence individual income and consumption of married men and women follows from a number of models in Becker (1973) and the Treatise.

\footnotetext{
${ }^{1}$ Becker's earlier economic analysis of fertility (Becker 1960) appeared in a conference volume.

${ }^{2}$ Becker $(1981,1991)$ is one of his most cited publications according to Google Scholar in 2014. The second edition published in 1991 is identical to the first edition (Becker 1981), except for a new introduction and the renumbering of chapters.

${ }^{3}$ For a more complete overview of Becker's theory of marriage see Grossbard (2010).
} 
2.1.1 Becker (1973) contains two D\&S analyses of sex ratio effects. In Becker (1973, Fig. 1) presents a market for men willing to marry. He assumes monogamy, that all men are identical, and that all women are identical. Marriage involves a total merger of income, resources and home production. The share of the full marital income that men access if they marry is men's implicit price in marriage. Men are willing to enter marriage as long as their marital income equals what they would get as singles. Their supply takes the shape of an inverted L. Once all men have entered the market, the supply becomes vertical. Women's demand is horizontal at the maximum share of marital income that men can possibly get, namely the total marital income minus what women would obtain if they remain single. Demand becomes a vertical line when all women have entered. At their intersection the demand and the supply establish the equilibrium "price" of men. The first figure in the Chapter on polygamy in the Treatise (Becker 1981, 1991) has the same graph, except that it has number of women on the horizontal axis, the supply is by women, the demand is by men, and the market equilibrium establishes a similar implicit price for women.

The major insight that Becker derives from this simple D\&S analysis is that the higher the sex ratio (the more men relative to women, following a demographers' convention) the higher the price of women in marriage, which can be reflected in women's increased access to marital income and consumption benefiting women more than men. ${ }^{4}$

Becker (1973) expanded this D\&S analysis of sex ratio effects to marriage markets for women and men of a particular type when there are large numbers of types of men and women who could serve as substitutes. That model, that some have called a hedonic market model, ${ }^{5}$ includes a Marshallian D\&S model for a particular type of man $M_{i}$ and a particular type of woman $F_{j}$ (Becker's 1973, Fig. 2). ${ }^{6}$ As in Becker's (1973) first model, men are on the supply side and women on the demand side. There are $(I-1)$ other types of men and $(J-1)$ other types of women. It is assumed that together an $\left(M_{i}, F_{j}\right)$ couple can produce marital output $Z_{i j}$. If men stay single their output is $Z_{i 0}$ and if women stay single their output is $Z_{0 j}$. Women's demand is downward-sloping: the more income/output women $F_{j}$ share with men $M_{i}$, i.e. the higher the price of this type of husband, the less women are interested in marrying them rather than marrying a man from a substitute type. Men's supply is upward-sloping: the larger the share of output (i.e. the higher the price) they get from this type of woman, the more men $M_{i}$ are likely to switch from other types of women to marry women $F_{j}$. All individual demands and supplies for these two types are aggregated and an equilibrium division of output $\left(m_{i j}\right)$ is obtained at the intersection of demand and supply, namely point $e_{0} \cdot Z_{i j}=m_{i j}+f_{i j}$ and $Z_{i j}$ is given, and therefore this equilibrium also implies the price of women $f_{j i}$. At that point both men $M_{i}$ and women $F_{j}$ are satisfied being with each other rather than being in couple with a substitute of type $k$.

To the extent that the sex ratio increases in a particular market men's price will decrease and women's price will increase, thus leading to a higher share of marital consumption benefiting women. Given that different types of men and women are either substitutes or complements

\footnotetext{
${ }^{4}$ When the number of men equals the number of women the price is not determined precisely: it will be in the range defined by the maximum price on the demand and the minimum price on the supply.

${ }^{5} \mathrm{Rao}(1993)$ is possibly the first to have used the term 'hedonic' to describe this kind of multi-market D\&S model of marriage.

${ }^{6}$ Becker defines this market for women of type $i$. I follow the notation used by Choo and Siow (2006), a marriage market model inspired by this Becker model that has been called a hedonic model by Siow (2007) and a matching model (e.g. by Chiappori and Salanie 2014; Abramitzky et al. 2011). As pointed out by Chiappori and Salanie (2014) there are close links between hedonic D\&S models and TU matching models.
} 
changes in sex ratio in one marriage market can also affect prices in many other marriage markets. A higher aggregate sex ratio in the economy does not necessarily translate into a higher sex ratio in each $\left(M_{i}, F_{j}\right)$ marriage market.

2.1.2. In the Treatise Becker (1981) also analyzes sex ratio effects. In addition to Becker's (1973) first D\&S model assuming monogamy, identical men, and identical women, the Treatise presents a D\&S analysis of sex ratio effects assuming identical men, identical women, and that polygyny is possible. Here women are on the horizontal axis, as in Grossbard (1976), in contrast to Becker's (1973) markets for husbands. Men's demand has a few steps, reflecting diminishing marginal productivity of plural wives. Furthermore, in a more general analysis not taking the form of a D\&S model, Becker (1981) considers many types of man differing in efficiency (defined as a continuous variable) but only one type of woman.

All of Becker's models of sex ratio effects lead to the same prediction: sex ratios will be directly related to women's share of marital income and their personal consumption in marriage.

2.2 Evidence. Becker $(1973,1981)$ suggests that to test this prediction (and how other factors affect implicit prices in marriage markets) future research could use information on what is now called 'assignable consumption', such as spending on husband's and wife's clothing, or on leisure. Becker's prediction regarding sex ratios and consumption has recently been tested. Most tobacco and alcohol is consumed by men and can therefore be assigned to men. This is also the case in mainland China where Maria Porter (2014) found that as sex ratios are higher, and women are scarcer in marriage markets, men consume less tobacco and alcohol. Furthermore, prior research has shown that, relative to fathers, mothers prefer to invest more in their children's human capital (e.g. Duncan Thomas 1990, Brown 2009). Porter also establishes that in China higher sex ratios are associated with healthier sons and she shows that this not fully explained by the characteristics of the parents. Both the negative effects of sex ratios on consumption of tobacco and alcohol and their positive effect on sons' health can thus serve as evidence that sex ratios are positively associated with married women directing more of the household's resources towards consumption that satisfies their preferences rather than their husbands'.

2.3 Expansions of Becker's analyses. Becker's models led to the prediction that sex ratios are associated with a married person's implicit price in marriage and their personal consumption. His analysis has been expanded to sex ratio effects on savings and labor supply. A relatively simple way to do so starts with dropping Becker's assumption that marriages are total mergers between two individuals, as in Grossbard (1976) and Grossbard-Shechtman (1984). Instead, I have assumed that individuals remain independent decision-makers whether they are married or not. Rather than complete mergers, marriages are small non-profit firms with one or more spouses doing household production work. Marriage institutions regulate labor contracts between independent spouses, in a manner similar to how employment institutions regulate labor contracts between workers and employers (see Grossbard-Shechtman and Lemennicier 1999). Work-In-Household (WiHo) is defined as time in household production that benefits a spouse and Becker's markets for husbands or wives are replaced with markets for WiHo. ${ }^{7}$ Adapting Becker's sex ratio analyses to markets for WiHo and adding the assumption of traditional gender roles leads to the same prediction that Becker obtained: higher sex ratios will be associated with higher implicit prices for women. However, in this case the implicit price is not the price of a person (husband or wife) as in Becker, it

\footnotetext{
7 WiHo is the term used in Grossbard (2015a). In Grossbard (1976), in the context of Maiduguri, Nigeria, in the 1970s WiHo was called 'wife services'; Grossbard-Shechtman (1984) generalized the concept to all genders and called it 'household labor'.
} 
is the price of the time that a WiHo-working spouse spends working for the benefit of another spouse. That price influences the disposable personal income of WiHo-workers and WiHo-users, thereby affecting not only their consumption, but also their labor supply and savings.

Higher sex ratios imply higher implicit prices of women's WiHo where traditional gender roles prevail, thus raising women's opportunity cost of work in the labor force and leading men to have to pay more to realize their family-related preferences. Therefore, when sex ratios are higher women (men) will supply less (more) labor to the labor market (Grossbard-Shechtman 1984). Sex ratios vary across cohorts due to fluctuations in fertility if there is a relatively fixed difference in men and women's age at marriage. ${ }^{8}$ Using cohort variation in sex ratio for the years 1965-2005 for four U.S. regions and multiple cohorts Grossbard and Amuedo-Dorantes (2007) showed that the higher the sex ratio the less married women are likely to participate in the labor force. Grossbard-Shechtman and Neideffer (1997) and Chiappori et al. (2002) have shown that women supply less labor and men supply more labor when sex ratios are higher in a particular geographical area.'

Sex ratios also affect savings, as has recently been documented by Du and Wei (2013) and Wei and Zhang (2011) using Chinese and cross-country data. They find that savings rates rise when sex ratios are higher. This is consistent with an analysis of sex ratio effects on marriage markets assuming traditional gender roles and that changes in overall savings are dominated by changes in men's savings. A higher implicit market price for women working in WiHo after marriage (due to higher sex ratios) implies that men may be induced to save more prior to marriage, so they can better afford marriage. More on this topic is found in Grossbard and Pereira (2010) and Grossbard (2015a).

\section{The value of women under polygyny and brideprice}

Polygyny is a particular form of polygamy involving men marrying multiple wives. Becker first analyzes this topic in Becker (1974) in a section pertinently entitled 'polygamy' and then in the chapter on polygamy in Becker (1981). He examines many determinants of the likelihood that societies have polygamy and that individual men and women live in polygynous households. He also analyzes consequences of polygyny. Becker (1974, pp S19-20) claims that allowing polygyny is good for women: "Surely, laws against polygyny reduce the "demand" for women, and thereby reduce their share of total household output and increase the share of men" and "the laws that prevent men from taking more than one wife no more benefit women than the laws in South Africa that restrict the ratio of black to white workers benefit blacks".

In the Treatise Becker (1981, p. 56) drops these strong statements, but in response to "groups opposing polygyny [who] claim to be opposed to the degradation and exploitation of women" he continues to state that polygyny is good for women. His conclusion is based on a D\&S analysis of marriage, an analysis similar to that of the effect of a higher sex ratio: under a polygynist regime it is as if there were more men in the market than under monogamy. However, as Grossbard (1980) and Becker (1981) point out, allowing the same men to enter a market for wives twice does not have the same effect as the presence of twice as many men. Even if all men are identical and women are plotted on the horizontal axis, under polygyny men's demand becomes a step function to the extent that wives have diminishing marginal productivity when one factor in marital production is fixed: the husband's time. The gain from marriage, and what men are willing to pay for a wife, will then be a decreasing function of the number of wives already in the household. Nevertheless, as shown in

\footnotetext{
${ }^{8}$ The higher men's age at marriage relative to that of women the smaller the impact of an imbalance in the sex ratio of people the same age (d'Albis and de La Croix 2012).

${ }^{9}$ However, since migration could be the result of better labor market opportunities it is hard to prove that in these geographical comparisons the causality runs from sex ratio to labor supply.
} 
Becker (1981, Fig. 3.2) the demand for wives is higher under polygyny than under monogamy, and for a given supply of women their market price and access to marital income will increase. ${ }^{10}$

Becker's argument can be explained with the help of Fig. 1 depicting juxtaposed markets for wives in two otherwise identical societies, except that one allows polygyny and the other does not. The quantity dimension is number of wives. The implicit price of wives is $f$, women's share of marital full income (including home production). To make the analogy with other D\&S analyses more apparent I drop the assumption of identical men and identical women and assume instead that there are many types of men and many types of women. In assuming this I follow Becker's (1973) hedonic D\&S model and traditional labor economics (see previous section).

$D_{1}$ is men's demand under polygyny: like employers who can hire more than one worker men can marry more than one woman. Individual men enter the market whenever a wife's value to them exceeds her market price $f$ and market demand is the sum of all individual men's derived demands at given prices for wives. The first men to enter are those with whom women generate the most marital surplus and those with higher marginal utility from marital output. The demand for wives is downward-sloping for at least two reasons: $1 /$ as men with lower productivity and utility from marital output enter the market they are willing to pay less to marry; and 2/ for a given man the gain from marriage to a particular wife is a decreasing function of the number of wives already in the household due to diminishing marginal productivity of wives.

Men's market demand for wives under monogamy, ${ }_{2}$, lies under $D_{1}$, reflecting the fact that men's individual demands for wives are capped to one wife only. The upper portion of demand $D_{2}$ corresponds to individual demands for first wives and coincides with that portion of $D_{1}$. However, as the number of wives on the horizontal axis increases, under monogamy men demand fewer wives: quantity demanded grows as price $f$ decreases due to the entry of less productive men, not due to reentry of polygynists.

The market supply is the sum of all individual supplies by women derived at given implicit prices $f$. Whenever that price exceeds their reservation income women enter the market. The market supply is upward-sloping as the women with the lowest reservation incomes enter first. Women's supply in a polygynist regime could lie above that under monogamy to the extent that women prefer not to share a husband and ask for a higher price from polygynists than from men offering monogamous marriage. However, for simplicity it is assumed that the supply is the same in both societies.

The market with polygyny clears at equilibrium $e$; the market imposing monogamy at equilibrium $e$ '. Under polygyny the demand is relatively higher and there is more male competition for relative scarce women who obtain a higher equilibrium income $f_{p}$ than they would under monogamy $\left(f_{p}>f_{m}\right)$. This higher implicit price translates into more access to consumption goods for married women. Therefore, according to Becker and my doctoral dissertation written under Becker's supervision (Grossbard 1978a) women are better off under polygyny than under monogamy. Becker (1981, p. 56; italics added) warns us, however, that marriage markets may not necessarily be competitive: "My analysis of efficient, competitive marriage markets indicates ... that the income of women ... would be greater when polygyny is greater if the incidence of polygyny had been determined mainly by the relative marginal contribution of women to output."

The price that women obtain in a polygynous marriage market may not fully capture their contribution to marital income based on their productivity and may be lower than $f_{p}$. For example,

${ }^{10}$ In the $2 \mathrm{~d}$ edition of the Treatise (Becker 1991) this is Figure 4.2. 
there may be a ceiling on the price of wives, which can be analyzed in light of Becker's (1981, pp 8687) D\&S analysis of price ceilings in marriage markets (where the term 'price ceiling' is not explicitly used). This is presented in the Treatise some thirty pages after his discussion of polygyny's value to women, in the following chapter and in a section about 'price' rigidities in marriage. As I show in Fig. 1 an effective price ceiling in a market for wives could prevent the market equilibrium price from being reached. ${ }^{11}$ In this case it is possible that women's share of marital income under polygyny will be lower than under monogamy to the extent that polygyny is accompanied with a substantial price ceiling but monogamy is not. For example, in Fig. 1 married women's income under "polygyny + price ceiling" $f_{c}$ is lower than their income $f_{m}$ assuming a competitive equilibrium under monogamy without a price ceiling. Women are also worse off under polygyny if there is a price ceiling on their marital income under both polygyny and monogamy, but the gap between equilibrium price and price ceiling is sufficiently larger under polygyny than under monogamy.

The question is then whether under polygyny women are likely to obtain their market value $f_{p}$ or whether they will get a marital income that has been substantially capped by a price ceiling, perhaps as low as $f_{c}<f_{m}$, implying that women are better off under monogamy than under polygyny. Inspired by Maria Guttentag and Paul Secord's (1983) ideas on sex ratios and Becker's analyses of "price ceilings" I wrote in 1993 that where polygyny is permitted men are more likely to deprive women from the share of marital income that they would obtain if they had access to their market value (Grossbard-Shechtman 1993, chap. 11). In 2010 I testified accordingly before the Supreme Court of British Columbia in Canada when it considered the legalization of polygyny (Bramham 2010), concluding that polygyny is likely to harm women.

Interestingly, Becker himself recognized that polygynous societies may cap women's share of marital income more than monogamous ones. In the chapter following the chapter on polygyny Becker (1981 pp 86-87) writes that "the difference between actual and equilibrium income is probably greater when [women's] equilibrium income is a larger share of marital output ("a larger share [of marital output] may not be as readily appropriated by wives", [my italics] ) ... "as in the following situations: in societies with a larger supply of men relative to women; ...in societies with a higher incidence of polygyny; and in patrilineal societies ... because husbands have more control over the division of marital output, especially over children, in such societies." However, in that later chapter Becker's focus was on explaining the institution of bride price, and he does not state how price ceilings are likely to hurt women's relative wellbeing under polygyny.

The incidence of bride price (paid by men or their relatives prior to marriage) and dowry (paid by women or their relatives prior to marriage) is positively correlated to the incidence of polygyny. Grossbard (1978a, 1978b) documents that correlation. Grossbard (1978a, 1978b) and Becker (1981, p. 56) use that correlation as evidence that married women are better off in polygyny than in monogamy, assuming that if the price of wives is higher men will pay more both during marriage and before marriage in the form of a bride price

A more complete recent study has confirmed the positive correlation between brideprice and polygyny (Tertilt 2005). ${ }^{12}$ However today I think that far from demonstrating that married women are better off under polygyny than under monogamy, that correlation provides evidence to the contrary: under polygyny women are worse off than under monogamy because under polygyny it is

\footnotetext{
11 This section of Becker's Treatise does not include a graph.

${ }^{12}$ It also showed that an outright ban on polygyny will lead to the disappearance of brideprices and to the emergence of groomprices (dowries).
} 
more likely that price ceilings are placed on their access to marital income. The institution of bride price serves as indirect evidence that such ceilings have been imposed. ${ }^{13}$

Becker (1981, Ch. 4, p. 87) hints to such alternative causality linking bride prices and polygyny: "the difference between actual and equilibrium income of wives is probably greater when their equilibrium income is a larger share of marital output (..). Therefore the frequency and magnitude of bride prices should be greater.. in societies with a higher incidence of polygyny." Becker does not explain why wives' actual income would diverge more from equilibrium income when equilibrium income is higher (possibly due to polygyny). One explanation follows from one of the reasons that Becker gives for why actual women's share of marital income is below market equilibrium: men, having "sometimes been given legal control over the assignment of shares [of marital output]" (Becker 1981, p. 86, citing Weitzman 1974, emphasis mine), may have more incentives to use their legal control to place a ceiling on women's marital income when women's relative equilibrium income in marriage is higher (for example due to polygyny). The excess demand for wives (aka shortage of wives) resulting from a price ceiling may lead to a bride price system. One can draw an analogy between rent controls and ceilings on women's price: both create shortages. In the case of housing, prospective tenants often 'bribe' landlords or current tenants into allowing them access to scarce and coveted rent-controlled housing. In the case of polygynous societies, bride prices allow men to gain access to scarce, highly valued women.

What social scientists also need to explain is the political economy of both polygyny and ceilings on women's marital incomes. While there is a literature on the political economy of polygamy, it deals mostly with the emergence and disappearance of polygyny regimes (e.g. Grossbard 1978b, Becker 1981, Kanazawa and Still 1999, de la Croix and Mariani 2012), not with explaining price ceilings on women's marital income as a function of polygyny. In these models the interest groups likely to 'lobby' for polygyny are the rich men and the poor or uneducated women, whereas poor men and rich or educated women are likely to oppose polygyny. The same rich men who would 'lobby' for polygyny's legalization would also prefer price ceilings on women's marital income that redistribute income in their favor. However, while some women (the least productive ones, who may otherwise remain unmarried) may support polygyny, one does not expect any women to 'vote' for caps on their own share of marital income. Wives' lower appropriations under polygyny (using Becker's language) may not be out of choice but a result of men controlling the relevant political and religious institutions to their own advantage.

It follows that, relative to monogamous societies, societies that allow polygyny are likely to also have limited women's influence in politics and society (Guttentag and Secord 1983). If polygyny was instituted and price ceilings are preventing women from enjoying their high market value it indicates that women may not have the power to oppose the combination of polygyny and price ceilings that benefits rich men. As for poor men they may oppose polygyny but not ceilings on women's share of marital income. They may thus form coalitions with rich men to maintain these combined institutions.

For the same reasons that polygyny is associated with caps on women's married income and the incidence of brideprice it is also associated with other institutions that tend to harm women (Grossbard 2015b). For example, polygynous societies also tend to (1) allow child marriages which curtail freedom to choose mates and tends to apply to girls more than boys (see Bramham 2009 for Canada), (2) encourage female genital mutilation (lowering women's sexual drive and thereby making it easier for polygynous husbands to satisfy all of their wives sexually, see Rahman and Toubia 2000),

\footnotetext{
13 A brideprice system is expected to be particularly harmful to women where brideprice is refundable, as is the case in Uganda. It has been found that when brideprice is refundable there are stricter standards of fidelity imposed on women than on men (David Bishai and Grossbard 2010).
} 
and (3) limit women's ability to earn income in the labor force. In African and Asian polygynous societies women are often secluded into 'purdah' (see Cohen 1971); the polygynous Fundamentalist Latter Day Saints communities in North America are often isolated and offer very limited employment opportunities to women (Bramham 2009). Anderson (2007) reports that bride price has been linked to domestic violence against women. Given the positive association between bride price and polygyny, could domestic violence also be associated with polygyny?

\section{Conclusions}

Becker's Demand and Supply (D\&S) models of marriage lead him to derive important insights regarding effects of sex ratios (the ratio of men to women in marriage markets) on marriage and individual consumption during marriage. Sex ratios can affect more economic decisions_-including labor supply and savings--because they affect the implicit price of men and women willing to marry and thereby contribute to household production and marital income. Recent empirical research confirms that sex ratios matter even when the focus is on traditional concerns of economic policy such as employment and savings.

Becker also relied on D\&S analysis to develop his argument that polygyny benefits women and used the positive association between brideprice and polygyny as evidence. However, based on D\&S analysis of marriage and on the section of Becker's Treatise on the Family dealing with "price" rigidities in marriage, I argue that polygyny may be harmful to women. Furthermore, it is shown that the positive association between brideprice and polygyny does not necessarily prove that women are better off under polygyny than under monogamy.

Becker's theory of marriage, of which D\&S models are an important part, counts among the most noteworthy expressions of his brilliant mind. It has already inspired generations of scholars and has the potential of inspiring many more. I hope that by presenting relatively simple D\&S analyses this article can help Becker's ideas gain further impact among scholars interested in family issues even if they don't have advanced degrees in economics, even if they disagree with some of the viewpoints that Becker expressed during his long and productive career (as stated before by Frances Woolley 1996), and even if they don't derive all the same conclusions from his theories.

Acknowledgments. I thank an anonymous referee, Eugene Choo and Aloysius Siow for their advice, and Hazem Alshaikhmubarak for research assistance. 


\section{References}

Abramitzky, Ran, Adeline Delavande and Luis Vasconcelos (2011) Marrying up: the role of sex ratio in assortative matching. American Economic Journal: Applied Economics, 124-157.

Anderson, Siwan (2007) The economics of dowry and brideprice. The Journal of Economic Perspectives, 151-174.

Becker, Gary S. (1960) An economic analysis of fertility. In Demographic and Economic Change in Developed Countries, a Conference of the Universities--National Bureau Committee for Economic Research. Princeton, N.J.: Princeton University Press. . (1965). A theory of allocation of time. Economic Journal 75:493-515. . (1973) A theory of marriage: part I. Journal of Political Economy 81, 813-846. (1974) A theory of marriage: part II. Journal of Political Economy 82, 511-26. (1981) A Treatise on the Family. Cambridge, MA: Harvard University Press (2 ${ }^{\text {nd }}$ edition 1991).

Bishai, David, and Shoshana Grossbard (2007) Far above rubies: the association between bride price and extramarital sexual relations in Uganda. Journal of Population Economics 23(4), 1177-1188.

Bramham, Daphne (2009) The Secret Lives of Saints: Child Brides and Lost Boys in Canada's Polygamous Mormon Sect. Toronto, Canada: Vintage. - (2010) Polygamy's many wives don't capture 'market value'. Vancouver Sun, December 9.

Brown, Philip H. (2009) Dowry and intrahousehold bargaining: evidence from China. Journal of Human Resources 44(1), 25-46.

Chiappori, Pierre-Andre (2015) Gary Becker's contribution to the economics of matching and marriage. Journal of Demographic Economics 1(1),x.

Chiappori, Pierre-Andre, Bernard Fortin and Guy Lacroix Chiappori (2002) Marriage market, divorce legislation, and household labor supply. Journal of Political Economy, 110, 37-71.

Chiappori, Pierre-Andre and Bernard Salanie (2014) The econometrics of matching models. Working paper, Columbia University.

Choo, Eugene and Aloysius Siow (2006) Who marries whom and why. Journal of Political Economy 114(1), 175-201.

Cohen, Ronald (1971) Dominance and Defiance. Washington: American Anthropological Association. d'Albis, Hyppolite and David de la Croix (2012) Missing daughters, missing brides? Economics Letters 116, 358-360.

de la Croix, David and Fabio Mariani (2012) From polygyny to serial monogamy: a unified theory of marriage institutions. IZA DP No. 6599.

Du, Qingyuan and Shang-Jin Wei (2013) A theory of competitive saving motive. Journal of International Economics 91, 275-289.

Grossbard, Amyra (1976) An economic analysis of polygamy: the case of Maiduguri. Current Anthropology 17, 701-7.

- (1978a) Towards a marriage between economics and anthropology and a general theory of marriage. American Economic Review 68, 33-37.

. (1978b) The economics of polygamy. Unpublished Ph.D. Dissertation, University of Chicago. . (1980) The economics of polygyamy. In J. DaVanzo and J. Simon (eds.), Research in Population Economic, Vol. II. Greenwich, CT: JAI Press.

Grossbard, Shoshana Amyra (2010) How 'Chicagoan' are Gary Becker's economic models of marriage? Journal of History of Economic Thought 32(3), 377-395.

- (2015a) The Marriage Motive: A Price Theory of Marriage. Why Marriage Markets Affect Employment, Consumption and Savings. Springer. 
. (2015b) Polygamy and the regulation of marriage markets. In Janet Bennion and Lisa Fishbayn Joffe (eds.), The Polygamy Question. Logan (Ut.):Utah State University Press/University Press of Colorado, forthcoming.

Grossbard, Shoshana and Catalina Amuedo-Dorantes (2007) Marriage markets and women's labor force participation. Review of Economics of the Household 5, 249-278.

Grossbard, Shoshana Amyra and Alfredo Marvao Pereira (2010) Will women save more than men? A theoretical model of savings and marriage. (No. 3146). CESifo working paper Fiscal Policy, Macroeconomics and Growth.

Grossbard-Shechtman, Amyra (1984) A theory of allocation of time in markets for labor and marriage. Economic Journal 94, 863-82.

Grossbard-Shechtman, Shoshana (1993) On the Economics of Marriage. Boulder: Westview Press.

Grossbard-Shechtman, Shoshana and Bertrand Lemennicier (1999) Marriage contracts and the Lawand-Economics of marriage: an Austrian perspective. Journal of Socio-Economics 28: 665-690.

Grossbard-Shechtman, Shoshana and Matthew Neideffer. (1997) Women's hours of work and marriage market imbalances. In Inga Persson and Christina Jonung (eds.) Economics of the Family and Family Policies. London: Routledge, 1997.

Guttentag, Marcia and Secord, Paul F. (1983) Too Many Women: The Sex Ratio Question. Beverly Hills: Sage Publications.

Kanazawa, Satoshi and Mary C. Still (1999) Why monogamy? Social Forces 78(1):25-50.

Mincer, Jacob (1962) Labor force participation of married women: a study of labor supply." In H.

Gregg Lewis (ed.) Aspects of Labor Economics. Princeton, N.J.: Princeton University Press. . (1963) Market prices, opportunity costs, and income effects," in C. Christ (ed.) Measurement in Economics. Stanford, CA: Stanford University Press.

Papps, Ivy (1983) The role and determinants of bride price: the case of a Palestinian village. Current Anthropology 24, 203.

Porter, Maria (2014) How do sex ratios in China influence marriage decisions and intra-household resource allocation?. Review of Economics of the Household, 1-35.

Rahman, Anika and Toubia, Nahid (2000) Female Genital Mutilation: A Guide to Laws and Policies Worldwide. London and New York: Zed Books.

Rao, Vijayendra (1993) The rising price of husbands: a hedonic analysis of dowry increases in rural India. Journal of Political Economy 101(4), 666-677.

Siow, Aloysius (2007) Communication by email to the author, October 30.

Tertilt, Michele (2005) Polygyny, Fertility, and Savings. Journal of Political Economy 113(6), 1341-71

Thomas, Duncan (1990) Intra-household resource allocation: an inferential approach. Journal of Human Resources 25, 635-664.

Wei, Shan-Jin and Xiaobo Zhang (2011) The competitive savings motive: evidence from rising sex ratios and savings rates in China. Journal of Political Economy 119(3), 511-564.

Weitzman, Lenore J. (1974) Legal regulation of marriage: tradition and change. California Law Review 62(4): 1169-1288.

Woolley, Frances (1996) Getting the better of Becker.” Feminist Economics 2:114-120. 


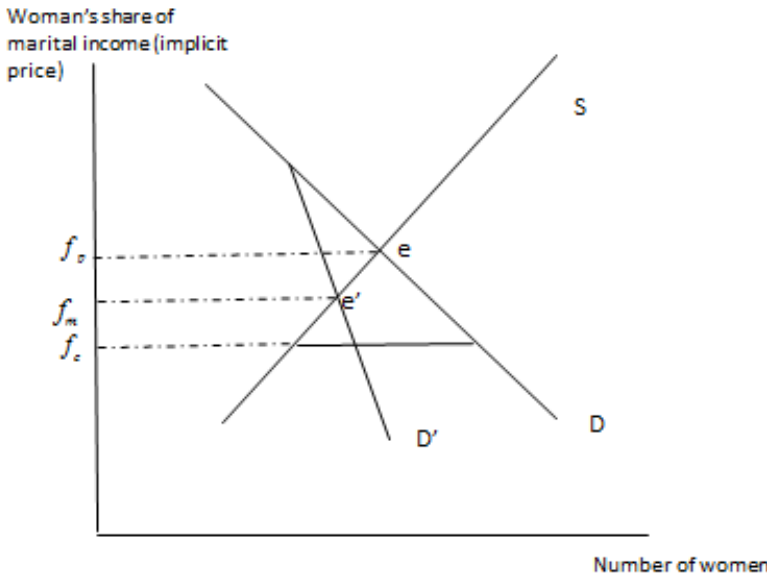

Figure 1: Market for wives 